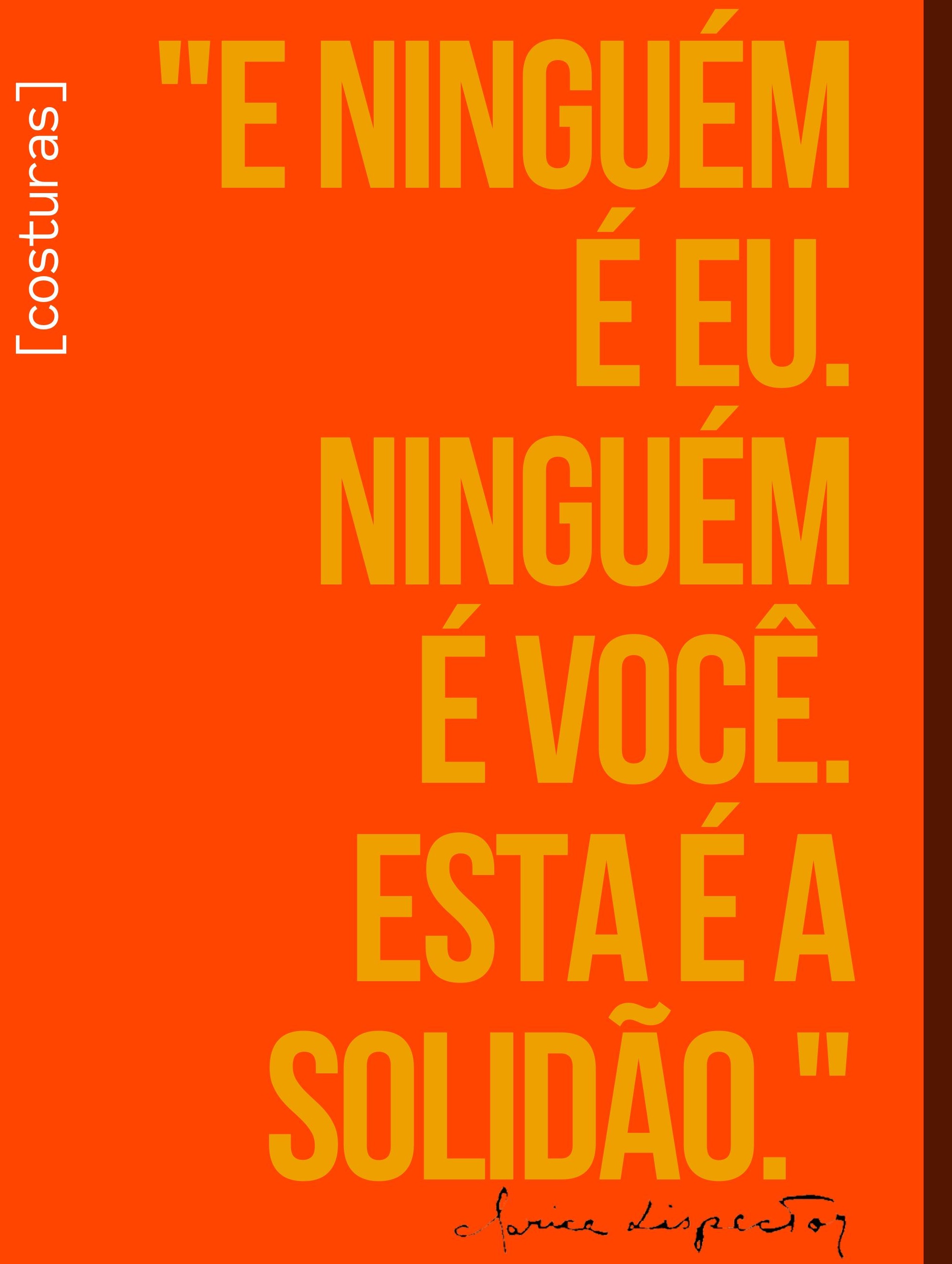




\title{
Vestindo-se para o sucesso ${ }^{1}$
}

\author{
Dressing for success
}

1 Este texto é uma tradução de "Dressing for success", de Clair Hughes, publicado originalmente em Fashion in fiction - Text and clothing in literature, film, and television, editado por Peter McNeil, Vicki Karaminas e Catherine Cole (Berg Publishers, 2009). 


\section{Clair Hughes}

Há um relato oitocentista sobre a rainha francesa Maria Antonieta, no começo de um baile da corte, usando "um vestido azul repleto de safiras e diamantes. Ela era jovem, bela e adorada por todos - ainda assim, já estava próxima do abismo" (MENDEHLSOHN, 2006) ${ }^{2}$. Essa passagem foi citada na crítica de Daniel Mendehlsohn sobre o filme Marie Antoinette, de Sofia Coppola, para destacar o que ele acreditava ser o ponto fraco do longa: Coppola, ele diz, "oferece o vestido, mas não o abismo" (MENDEHLSOHN, 2006, p. 22). Aquela descrição verbal da aparência da rainha era, resumidamente, mais reveladora, mais dramática do que as imagens deslumbrantes do filme. 0 contraste feito por Mendehlsohn em seu relato levanta o questionamento de porque algo tão visual quanto o vestir deveria ser considerado no contexto da literatura. 0 que as palavras fazem pelo vestir? Para o crítico, era a sugestão das palavras - a implicação de haver profundezas abaixo da superfície - que concedia o drama. Vestir-se, para Roland Barthes (2009), é a matéria poética ideal: tocando o corpo, revela-se o eu, mas também se interage com o social - conformando-se, rejeitando, enganando ou seduzindo.

Mas o vestir também é o sinal mais óbvio de ordem e hierarquia no mundo da nova classe média que se tornou tema central do gênero romance. É posição e status exibidos em letras garrafais. É expressão de gosto individual dentro de limites sociais. É marca de ambição, respeito por si mesmo e respeito pelos outros. As gradações das distinções do vestir no momento em que a Europa transita de uma ordem aristocrática tradicional para uma nova burguesia são uma preocupação infinita para aqueles que viveram essa mudança. E, no romance, eles encontram algumas de suas descrições mais sutis e questionadoras. Neste artigo, que aborda as ambições de quatro heróis ficcionais, o abismo que aguarda o fracasso segue os passos deles - a aparência de sucesso deve ser mantida. Como Lucien de Rubempré reflete em As ilusões perdidas de Balzac, angustiado pela visão de um garoto de recados parisiense usando uma gravata como a sua, "essas aparentes pequenas coisas não atormentaram brilhantes existências? A questão da indumentária é, aliás, de enorme importância para os que querem parecer ter aquilo que não têm, pois essa costuma ser a melhor maneira de possuí-lo, mais tarde" (BALZAC, 2011, p. 147). As ambições de Lucien não podem aparentar ser as mesmas de um garoto de recados. 0 que esses jovens querem, e como se vestem para consegui-lo?

Lucien é uma figura central na minha história. Mas quero olhar primeiro para os heróis de Goethe de 1774 e 1786, Werther e Wilhelm Meister - que, de acordo com o estudo de Franco Moretti sobre o romance novecentista, The way of the world, são heróis iniciais do bildungsroman ${ }^{3}$ europeu. Como o título Os sofrimentos do jovem Werther sugere, a jornada

\footnotetext{
As obras mencionadas pela autora que foram traduzidas e publicadas no Brasil são referenciadas e citadas neste texto de acordo com essas edições; aquelas que não estão disponíveis em português foram traduzidas a partir das citações da autora no texto original.

${ }^{3}$ Nota da tradutora: bildungsroman é uma palavra alemã utilizada largamente para se referir aos
} 
de Werther falha. Mas fornece uma peça-chave na história do vestir, assim como na história do romance, na forma de um paletó azul. De fato, o irrepreensível paletó azul poderia ser um subtítulo para este artigo, já que veremos um número surpreendente deles.

Depois de uma corte apaixonada a Charlotte, Werther descobre o casamento dela com outro e atira na própria cabeça: "Estava estendido perto da janela, imóvel e de costas, todo vestido e calçado, de casaca azul e colete amarelo" (GOETHE, 2010, p. 84). Uma carta para Charlotte afirma seu desejo de "ser enterrado nestas roupas [...] tu as tocaste, santificaste-as" (GOETHE, 2010, p. 84). As roupas simples de Werther, marca do homem nobre e natural, são parte da antimoda inglesa, difundida na Europa e baseada na roupa do campo: as vestimentas substanciais e sem estilo de Werther contrastam e desafiam a luxúria privilegiada da aristocracia alemã que o havia rejeitado. Werther falha, mas também é bem-sucedido. 0 romance best-seller fez com que jovens europeus se vestissem à la Werther, embora, felizmente, não puxassem o gatilho contra si mesmos com tanta frequência. A moda inspirada nessa imagem literária - e reforçada pela estética neoclássica - é a grande mudança no vestir na qual a aparência do homem moderno se baseia.

O bildungsroman é, de acordo com Franco Moretti, “o início da modernidade” (MORETTI, 2000 [1987], p. vii), e pertencer a seu tempo é o esforço central dos seus protagonistas: "Sei escolher o uniforme do meu século" (STENDHAL, 2013, p. 225), diz Julien Sorel, de Stendhal - infelizmente, não é sempre aquele que ele deseja. Com a nova noção de tempo histórico do fim do século XVIII, surge também uma preocupação com a autodeterminação individual e sua acomodação na sociedade. Para Moretti, o bildungsroman está situado não somente na fronteira entre duas épocas, "mas na fronteira [...] entre a burguesia e a aristocracia. É a história do jovem mercador, Wilhelm Meister, adotado por um grupo de latifundiários iluminados, e a jornada de Elizabeth Bennet de Cheapside até Pemberley; é a história de Julien Sorel, de Stendhal, e de Lucien de Balzac, a história de Jane Eyre" (MORETTI, 2000 [1987], p. viii). As garotas ambiciosas ficarão para uma próxima vez, mas lançarei um olhar sobre Wilhelm, Julien e Lucien, e também sobre Pendennis, de William Thackeray - e como eles se vestem para o sucesso.

O sucesso heroico não é atingido por meio do trabalho, pois a burguesia se preocupa indefinidamente com o que é ser um cavalheiro: Wilhelm Meister quer ser poeta, mas, insatisfeito com as suas conquistas, junta-se a um grupo de atores como dramaturgo. Entre os atores, a questão do figurino se apresenta. Wilhelm, até então em um terno cinza inexpressivo,

começou a refletir sobre seu modo de se trajar. Descobriu que um pequeno colete, sobre o qual, em caso de necessidade, poderia jogar uma capa curta, era um costume inteiramente adequado [...] Calças compridas de malha e um par de botas com cadarço lembravam-lhe o uniforme verdadeiro de um peão. Tratou de arranjar uma bela faixa de seda que ele cingiu ao redor do ventre [...] pareciam

romances de formação, especialmente os do século XIX. Embora possa ser traduzida, é utilizada na sua forma original pela maioria dos estudiosos do tema, por isso a opção por mantê-la. 
um gorjal antigo. 0 belo lenço de seda para o pescoço [...] estava frouxamente atado sob as pregas da musselina. Completava o disfarce um chapéu redondo com uma fita colorida e uma grande pluma. (GOETHE, 1994, p. 156)

O modelo declarado de Wilhelm é Prince Hal, de Shakespeare - a literatura oferece o ambiente de preferência desses heróis e as peças de Shakespeare estavam, então, em todo o seu furor. A perspectiva da descrição, como podemos notar, não é distante; ela internaliza $o$ ato de experimentar roupas. A sequência de vestimentas, terminando com um chapéu dramático, reflete o ato de se vestir e conferir os efeitos. As calças longas e as botas são características de 1780, mas a capa, o chapéu, a faixa e o rufo são furtados do guarda-roupa do teatro; ao chamar suas roupas de disfarce, a sugestão é de que Wilhelm estava incerto quanto ao efeito final.

Após ser ferido em uma briga com assaltantes, Wilhelm é resgatado por uma bela moça, que enrola seu "largo capote masculino" ao redor dele: "Um calor elétrico parecia emanar da fina lã" (GOETHE, 1994, p. 168-170). Ela desaparece, mas Wilhelm, declarando que ela era sua rainha amazona, promete encontrá-la novamente. Desiludido com os atores, ele é recebido em uma sociedade de nobres filantropos. Werner, um velho amigo e parte dessa comunidade, dá-lhe um olhar de aprovação: a aparência anterior de Wilhelm, diz ele, podia ser encantadora, "o peito seminu, uma grande gorjeira [...] chapéu redondo, colete curto e calças compridas e largas, enquanto eu sustentava que um traje como aquele não estava senão a dois dedos de distância da roupa de um arlequim. Agora, tens a aparência de um homem" (GOETHE, 1994, p. 362). "Estar vestido", disse Mick Carter (em correspondência pessoal), "nunca atinge realmente o status de 'natural", um conceito crucial para os românticos. 0 novo visual de Wilhelm, portanto, é inespecífico; esse visual masculino é de alguma forma intuído e compreendido como "natural" pelo autor e pelo leitor.

Wilhelm é finalmente declarado um "homem". Uma peculiaridade desse romance, no entanto, é que suas mulheres usam vestes masculinas. 0 primeiro amor de Wilhelm, Mariane, veste-se como um soldado; a dedicada Mignon usa uma réplica das primeiras roupas de Wilhelm, as cinzas; Therese, a quem Wilhelm pede em casamento, supervisiona sua propriedade em um terno de homem - e há a amazona, em seu eletrizante paletó. Estaria Goethe sugerindo que coragem, fidelidade, eficiência e filantropia são virtudes morais personificadas por mulheres as quais Wilhelm precisa amar para adquirir e atingir uma masculinidade? Não tenho nenhuma certeza sobre o que Goethe está tentando dizer aqui. 0 desenlace revela que Natalie, uma das nobres da sociedade, é a bela amazona de Wilhelm. As ligações anteriores dele são rapidamente dispensadas para permitir a união dos dois e o cumprimento da "busca nobre e emocionante de melhoria" de Wilhelm (GOETHE, 1994, p. 403). Nós esperamos que as qualidades eletrizantes de Natalie não estejam limitadas ao seu paletó.

A aparência teatral de Wilhelm é um aspecto do seu ego; não é falsa, mas é incompatível com a sua socialização. Diferentemente de Julien Sorel, cujos desejos acendem a narrativa de $O$ vermelho e o negro, de Stendhal, as ambições de Wilhelm são vagas, expressas de forma passiva. Os heróis de Stendhal, de acordo com o crítico francês Jean-Pierre Richard, não esperam que as coisas aconteçam: "A vida [é] uma selva de sensações indomadas pela qual 
um caminho prazeroso precisa ser construído [...] a sensação é um risco, assim como é uma recompensa, o prêmio pela coragem" (RICHARD, 1954, p. 20). Julien não busca harmonia com a sociedade da Restauração Bourbon de 1830: sob uma performance de conformidade, ele alimenta uma rebelião e sonhos de glórias napoleônicas. 0 vestir é o tecido do estado mental de Julien, uma máscara complacente debaixo da qual fervem emoções intensas.

0 título do romance destaca um contraste aparentemente relacionado às vestes: o vermelho militar e o preto clerical - mas nada é tão simples. A Guarda Revolucionária Francesa vestia vermelho, mas os príncipes da igreja também o faziam. 0 preto vestia o baixo clero e havia sido a cor das vestes de comerciantes, mas, em 1830, o preto, respeitável, estava se estabelecendo entre a população masculina da classe média europeia - uma mudança no significado que revela e esconde a trajetória da carreira de Julien. Financiado por um padre, Julien deixa sua casa de camponês para ser tutor da família Rênal, de quem recebe um terno preto: "O sentimento de orgulho que lhe dava o contato de roupas tão diferentes das que costumava usar punha-o de tal maneira fora de si" (STENDHAL, 2013, p. 27). A veste preta, como se sabe, é sobredeterminada: "Sexy, séria e um pouco sinistra", de acordo com Anne Hollander (2002, p. 128); “conspícua”, observa John Harvey, “mesmo que diga 'Não me veja! Eu me apago!'” (HARVEY, 1995, p. 13). Essa mistura de drama e decoro serve bem a Julien: seu "rosto de moça, tão pálido e doce" (STENDHAL, 2013, p. 22) é destacado pelo preto, mas as associações clericais da cor também garantem que ele é inofensivo. Não é o seu terno, no entanto, que seduz Madame de Rênal, e, sim, seu instinto para roupas limpas, uma preocupação típica do dândi e de seu tempo. Quando ela vê “o extremo asseio do vestuário, aliás muito simples, do jovem padre”, ela pensa, "pobre rapaz, como ele se arranja?" (STENDHAL, 2013, p. 30).

Madame de Rênal organiza um dia de glória vertiginosa para Julien. Ela lhe dá "um daqueles belos trajes azul-celeste com dragonas de coronel, prateadas" (STENDHAL, 2013, p. 74) para acompanhar uma marcha real pela cidade. 0 contraste do romance pode ser o vermelho e o preto, mas o azul parece ter um significado especial na cartela de cores de um jovem. A felicidade de Julien "não teve mais limites [...] era ajudante de ordens de Napoleão e comandava a artilharia" (STENDHAL, 2013, p. 75) - um figurino de pura fantasia cheia de alegria. 0 dia termina, no entanto, com um encontro com um jovem bispo em vestes púrpuras e rendadas tão caras que Julien para abruptamente: "Tão jovem, pensava, e ser bispo de Agde! [...] E quanto isso rende?”. A visão do bispo, então cercado por garotas bonitas, “fez nosso herói perder o que lhe restava de razão. Naquele instante, ele teria combatido pela Inquisição" (STENDHAL, 2013, p. 80-81).

Diante da ameaça de ter seu caso com Madame de Rênal exposto, Julien parte para o seminário. Seu sucesso lá leva à sua nomeação como secretário do Marquês de la Mole, em Paris. "Vestirá o traje preto", diz seu superior, "mas como um homem que está de luto, não como um eclesiástico" (STENDHAL, 2013, p. 165). 0 preto, então, é um novo preto, e Julien é enviado às compras. Apesar de seu novo guarda-roupa, a humilhação o aguarda. Na primeira noite, o marquês "olhou com uma insatisfação evidente as botas de Julien [...] 'não lhe disse que diariamente, às cinco e meia, deve vestir-se'”. Julien fica confuso. "- Quero dizer, vestir meias” (STENDHAL, 2013, p. 171). E é confuso, mas se olharmos para o retrato do Barão Schwiter pintado por Delacroix em 1827, em que ele está em vestes noturnas semiformais, 
com sapatos e meias, vemos o visual requerido. As agressões, naquele dia, por causa de suas roupas, não acabam por aí, pois quando o conde Norbert, filho do marquês, entra usando botas e esporas, Julien fica furioso; "e eu devo estar de sapatos, aparentemente como inferior" (STENDHAL, 2013, p. 172) - e nesse ponto o leitor pode se perguntar quem Julien pensa que é. Por outro lado, podemos considerar seu atrevimento, ou sua ingenuidade, revigorantes.

Julien se adapta rapidamente aos códigos da sociedade parisiense. "Ele tem estilo sem se dar conta disso" (STENDHAL, 2013, p. 259), reflete Mathilde, a filha do marquês. Uma beldade parisiense repara, em tom aprovador, que o paletó de Julien é um Staub, o melhor alfaiate da cidade. Se ele usa um uniforme por ordem dos outros, Julien agora controla seus efeitos, traduzindo vestes clericais em algo diferente, chique e sexy. "A vida dupla", diz Moretti, é "a chave para a personalidade moderna [...] Se o narrador de 0 vermelho e o negro não nos lembrasse de tempos em tempos a cor de sua vestimenta, quem se lembraria de que Julien é praticamente um padre?" (MORETTI, 2000 [1987], p. 87, 93). Ser quase um padre não é o mesmo que ser quase virgem ou quase grávida, mas no caso de Julien há algo daquela dicotomia liga/desliga que a roupa ajuda a clarificar - ou a confundir.

A performance de Julien não seduz somente Mathilde de la Mole, mas também o pai dela. Sua afeição por Julien perturba seu orgulho; aquele terno preto eterno é um lembrete diário da diferença social. "Permita, meu caro Sorel”, ele diz, "que lhe presenteie com um traje azul: quando quiser vesti-lo [...] você será, a meus olhos, o irmão caçula do conde de Chaulnes". O dia de Julien torna-se, então, esquizofrênico. Toda manhã, em um paletó preto, era "recebido à maneira antiga. À noite, de traje azul, o tom [era] completamente diferente". Mas Julien é agradável o dia todo, então o marquês, ainda inquieto, dá-lhe uma medalha Légion d'Honneur - "Não quero fazê-lo abandonar seu traje preto [...] quando eu vir essa medalha, você será o filho caçula de meu amigo, o duque de Chaulnes" (STENDHAL, 2013, p. 191, 194) - um prêmio por serviços prestados à alfaiataria, poderíamos dizer.

Quando ele, então, engravida Mathilde, esperamos a catástrofe. Mas ao contrário: esses desvios amorosos, consequentes de seu crescente fascínio, parecem na verdade aprofundar seus objetivos revolucionários. Para proteger a honra da família, Julien é aceito como o pretendente de Mathilde e transformado em oficial hussardo. Triunfante, Julien torna-se "um dos homens mais bem-vestidos de Paris" (STENDHAL, 2013, p. 445). Mas, ao mesmo tempo, os inimigos dão as caras: Madame de Rênal envia uma carta ao marquês denunciando Julien. Ele deixa Paris, encontra Madame de Rênal em oração na igreja e atira contra ela duas vezes. Ele é preso e condenado à morte.

No tribunal, "vestido com muita simplicidade, mas com uma graça perfeita", Julien ataca a sociedade por punir, por meio dele, "jovens que, nascidos numa classe inferior [...] têm a [...] audácia de misturar-se àquilo que o orgulho dos ricos chama a sociedade". Finalmente, em "grande manto azul sobre o soalho", nós vemos "o que restava de Julien" (STENDHAL, 2013, p. 353). Nem vermelho, nem preto, mas envolto no paletó de um oficial e de um cavalheiro, os sonhos de Julien permanecem intactos. A morte é o sucesso, pois, no mundo de valores simbólicos de Julien, não há acomodação nas realidades da França da metade do século XIX.

É esse o fim do herói romântico, a morte do paletó azul de Werther? A julgar pela abertura de As ilusões perdidas, de Balzac, de 1837, parece que sim. Lucien Chardon (mais 
tarde, de Rubempré), o filho de um químico provincial com um pequeno dom para a poesia, é convidado para o salão da Madame de Bargeton, centro da vida cultural de Angoulême. A irmã de Lucien usa suas economias para comprar-lhe "uma roupa nova no mais famoso alfaiate. Guarneceu sua melhor camisa com um jabô" (BALZAC, 2011, p. 56). David, noivo dela, reafirma a Lucien seu sucesso: "[você] tem ares de fidalgo dentro de sua casaca azul de botões amarelos e uma calça simples de nanquim" (BALZAC, 2011, p. 79). Mas, no salão de Madame de Bargeton, Lucien fica inquieto, "pois estava de botas [...] Sixte du Châtelet [seu rival] vestia calças de uma brancura deslumbrante, com presilhas internas, [...] sapatos finos e meias de fio de escócia [...] colete branco [...] a casaca preta se recomendava pelo corte e pelo estilo parisienses" (BALZAC, 2011, p. 79). Du Châtelet esnoba Lucien, que jura vingança.

Embora somente sete anos separem $O$ vermelho e o negro de As ilusões perdidas, passamos para um mundo estético e social completamente diferente. As imagens de Julien vestido eram vívidas, mas vagas em detalhes. Balzac, por outro lado, fala sobre o fio da meia, o tecido da calça e as correias. Não são somente impressões que ocupam Balzac: ele ama o detalhe em toda a sua amplitude e ambiguidade. Em seu Tratado da vida elegante, Balzac explica que as hierarquias desapareceram com a Revolução, "restam apenas nuances [...] efeitos de uma boa formação [...] que separam o homem do ócio do homem do trabalho". Você pode, diz ele, distinguir "o burocrata pelo desgaste de suas mangas [...] o flanêur pelos bolsos deformados pela frequência com a qual ele coloca suas mãos neles [...] a jaqueta de botões dourados do antiquado [provincial] ou a spencer suja do avarento [...] esses são sinais infalíveis de profissões, costumes e hábitos" (BALZAC, 2016, p. 67). Tais sinais podem ser revelados, precisam ser escondidos ou ser imitados.

Henry James disse que Balzac nos dá "o maquinário da vida, sua mobília e acessórios" (JAMES, 1984b, p. 97); mas estes "são descritos somente até o ponto em que eles têm um peso nas ações" (JAMES, 1984a, p. 608). Em As ilusões perdidas, as roupas praticamente são a ação. Lucien e Julien, por exemplo, ambos têm dias ruins com seus sapatos: Julien, com seus sapatos, ressente as botas do oficial aristocrata; as botas de Lucien são demais em um salão literário. As escolhas de Julien são limitadas por seu status como empregado, mas o burguês Lucien, livre para exercer seu gosto, empenha-se na vingança, no sucesso literário e em um novo guarda-roupas em Paris.

Uma vez lá, Lucien vê que Louise de Bargeton está ultrapassada. Ao mesmo tempo que ela acha Lucien "singularmente vestido", o provincianismo barato de sua aparência é "prodigiosamente ridículo" (BALZAC, 2011, p. 144). 0 próprio Lucien submete-se a "duas horas cruéis nas Tuileries: [...] sua casaca cujo corte passara de moda, cujo azul era desbotado, cuja gola era ultrajantemente sem graça [...] os botões estavam avermelhados, [...] seu colete era [...] tão grotescamente provinciano [...] só via calças de nanquim nas pessoas do povo" (BALZAC, 2011, p. 146). A roupa de Lucien pode ser identificada no estudo de Madeleine Delpierre sobre a vestimenta francesa: calças amplas e colarinhos xaile são típicos da década de 1820; depois de 1834, a silhueta se alonga, colarinhos e calças se estreitam e cintas para calças são de rigor. 0 paletó de corte em azul, verde ou preto com botões dourados, popular nas primeiras décadas do século, em 1840 estava sendo substituído pelo fraque contornado. 
Lucien corre ao seu hotel para buscar dinheiro e "se vestir dos pés à cabeça" (BALZAC, 2011, p. 149). Quando Julien de Stendhal vai ao seu quarto, é para checar consigo mesmo que suas ações estão de acordo com seus ideais. Mas o Lucien de Balzac não sofre nenhum questionamento interior; a mobilidade social é um fim em si mesma, e ele monitora seu progresso saindo para os lugares públicos da cidade - parque, bulevares, ópera -, em exibições de consumo de símbolos de status. Lucien vai à ópera vestindo suas compras: "Uma casaca verde, uma calça branca e um colete de fantasia [...] um par de botas muito elegante e na medida do seu pé [...] mas [se sentia] meio sem jeito dentro daquela espécie de estojo" (BALZAC, 2011, p. 149). Sua atenção é capturada por alguns jovens rapazes "cujo luxo de hoje era o de ontem, devia ser o de amanhã. Lucien pressentiu que estava parecendo um homem que se vestia pela primeira vez na vida" (BALZAC, 2011, p. 149). "O elemento mais essencial da elegância", avisa Balzac em seu Tratado, "é esconder os meios pelos quais ela é atingida [...] tudo que aspira a um efeito posterior é mau gosto" (BALZAC, 2016, p. 78). Olhando em volta, Lucien se dá conta "com secreta amargura que precisava se vestir com um alfaiate hábil" (BALZAC, 2011, p. 158).

Na Champs-Élysées, ele é interrompido por Louise em uma carruagem e uma visão da elegância parisiense. "A raiva, o desejo de vingança se apoderaram daquele homem [...] - Meu Deus! Preciso de ouro, custe o que custar! [...] Não! [...] é a glória, e a glória é o trabalho! 0 trabalho! [...] Mas hei de triunfar! Passarei nesta avenida de carruagem, com um lacaio!" (BALZAC, 2011, p. 162). Lucien, como Julien, encontra a resposta em Staub, com quem ele encomenda um fraque, um colete e calças. Mais tarde, reinventado, ele retorna aos bulevares, estando "tão bem-vestido, tão gracioso, tão bonito, que várias mulheres o olharam, e duas ou três ficaram bastante impressionadas com sua beleza a ponto de se virarem" (BALZAC, 2011, p. 163). Mas o capítulo termina com Lucien chorando, sozinho em Paris, sem amigos, desprotegido e - antes que fiquemos sentimentais - escrevendo uma carta suplicante para casa, pois ele arruinou as suas economias e as da sua irmã para todo o ano. Em busca de um estilo que garantisse seu sucesso, Lucien persegue uma quimera que está sempre à sua frente.

0 "trabalho duro" de Lucien é jornalismo de baixa qualidade, críticas de livros e teatros em que opiniões são vendidas por favores sexuais ou um punhado de ingressos. Coralie, uma atriz, torna-se sua amante e um artigo espirituoso traz-lhe fama. Mas a fama dura tanto quanto a moda das gravatas, e Coralie "[arruína-se] para dar a seu querido poeta aquele refinado vestuário dos elegantes": uma torrente de ornamentos se seguem, culminando em alguns "coletes miríficos em quantidade bastante grande para poder combinar com as cores de suas roupas" (BALZAC, 2011, p. 351). Mas os colegas de Lucien planejam a destruição do invasor: seu trabalho é rejeitado; Coralie adoece e morre. "O deplorável prodígio provinciano", como Balzac o chama, retorna a Angoulême.

Louise apadrinha Lucien novamente, lisonjeando-o com convites. Ele envia a Paris um pedido de roupas: "Pois preciso me endomingar a qualquer preço. Não tenho nada além de trapos" (BALZAC, 2011, p. 538), ele lamenta. Louise e seus acólitos estão, na verdade, atrás do cunhado de Lucien, David, dono de uma processadora industrial lucrativa. Lucien 
trai David em uma festa na qual ele é o mais moderno no que diz respeito à moda: "Uma calça preta colante [...] As meias de seda cinza rendilhada, os sapatos pequenos, o colete de cetim preto, a gravata, tudo foi escrupulosamente arrumado, colado" (BALZAC, 2011, p. 552) - uma última aposta em sua crença de que, se você aparenta ter o que não tem, você irá tê-lo. Aqui, o vestir como sinal socioeconômico colapsa; impecavelmente vestido, mas enganando somente a si mesmo, Lucien segue em direção à ruína. É irônico que nossa imagem de Balzac, baseada na estátua de Rodin, é a de um homem desajeitado, desarrumado. Mas a imaginação e a escrita de Balzac estão em outra esfera, ocupada pela comédia humana em que tudo pode ser importante, e roupas, status, dinheiro e boa aparência lutam sem descanso por um lugar. Mas as roupas, nesse caso, não determinam o que a pessoa é.

Moretti conclui que Balzac isolou em Lucien "as características febris e anárquicas do início do capitalismo [...] suas alternâncias enigmáticas entre sucesso e ruína” (MORETTI, 2000 [1987], p. 145-146). Não é a nobreza, a rebelião ou o gosto que motivam as decisões dele a respeito do que vestir: elas são respostas em pânico ao turbilhão de imagens da moda - ele não faz ideia do que está fazendo, nem do porquê. Em cada triunfo da roupa está também o fracasso, pois ele não consegue distinguir sinais do que eles representam. Seu paletó azul, descartado no início, ligava-o à família e ao lugar; as vestes subsequentes substituem umas às outras em um desperdício precipitado. Não há um fim lógico para suas ambições ou suas roupas, então, arrancado do desastre por um padre sinistro usando meias de seda pretas, o romance termina na carruagem para Paris - e a história de Lucien fica para ser contada em outro lugar ${ }^{4}$.

Lucien torna-se a "forma vazia" eviscerada na sátira de Thomas Carlyle, de 1832, Sartor Resartus. 0 alvo de Carlyle era o dandismo, representado por Conde D’Orsay, Disraeli e Bulwer-Lytton. $\mathrm{O}$ conjunto de Lucien na festa fatal está inserido no que John Harvey chama de "o estilo sombrio de dandismo" (HARVEY, 1995, p. 28), inspirado pelo herói elegantemente sombrio de Pelham, romance best-seller de Lytton; é um estilo que, de acordo com o romance, apenas os bem-nascidos podem ostentar. 0 novo mundo burguês do romance do século XIX é um fenômeno europeu cujas preocupações ressoam de um país a outro. A Inglaterra inventa a vestimenta do dândi - e as histórias inglesas têm seus próprios dândis, com roupas e ansiedades próprias de sua classe. Nós os vemos, por exemplo, em Pendennis, outro filho de um químico, herói do romance de Thackeray, Pendennis (1850).

Com a morte de seu pai, Pendennis (ou Pen) é deixado nas mãos de sua mãe e de seu tio, major Pendennis, um militar de sucesso. 0 major inicia o romance "com as melhores botas pretas de toda Londres [...] e linho tão impecável que o próprio sr. Brummell perguntou o nome de sua lavadeira" (THACKERAY, 1999, p. 1). 0 estilo camponês inglês, adotado pelos franceses, havia cruzado de volta o canal para ser refinado por Beau Brummell, amigo do príncipe regente, em um estilo não muito diferente das vestes militares - paletó preto em capa, colete claro, pantalões leves e justos, calçados finos e linho simples. 0 linho, na

\footnotetext{
${ }^{4}$ Depois de mais aventuras e muitas compras, Lucien finalmente morre em Splendeurs et misères des courtisanes (1844).
} 
verdade, tornou-se a pedra de toque da aparência correta: "[S]e você é econômico com seu alfaiate", diz o Manual de etiqueta para damas e cavalheiros (MANUAL DE..., 1853, p. 144), "você pode ser extravagante com sua lavadeira". 0 estilo de vida perdulário do príncipe, no entanto, levou o período regencial ao descrédito - embora, como apontado por Ellen Moers (1960), as atitudes vitorianas em relação ao dandismo fossem ambivalentes. A frivolidade era claramente condenada, mas havia algo atrativo, mesmo nostálgico, na forma como os dândis "faziam do absoluto egoísmo um sucesso" (MOERS, 1960, p. 14), e, como Thackeray admite no fim do romance, "nossa história é egoísta" (THACKERAY, 1999, p. 719).

Ao ver um colega de escola "em vermelho e dourado, com um imenso chapéu de pele de urso na cabeça" (THACKERAY, 1999, p. 28), Pen, assim como Julien Sorel, sente-se atraído pelo exército. Mas enquanto Julien sonha com a ação heroica, Pen deseja apenas a roupa e se distrai facilmente ao encontrar outro velho amigo, Foker, "em uma daquelas vestes a que o consenso geral atribuiu o nome de 'grã-fina'”. 0 grã-fino é uma figura da década de 1840 que vulgarizou o dândi: Foker veste "uma gravata de xaile escarlate [...] um [pingente de] buldogue de ouro [...] um colete de pele [...] um fraque verde com botões de cesto e uma sobrecasaca branca com botões grandes e achatados" (THACKERAY, 1999, p. 36-37). As ilustrações de Foker e Pen feitas pelo próprio Tackeray mostram Foker com dois coletes, calça xadrez e uma gravata larga; as roupas de Pen têm uma simplicidade regencial, atualizadas por um chapéu stovepipe e uma gravata borboleta dos anos 1840. "Simplicidade é a única distinção", afirma o Manual de etiqueta, "a que um homem de bom gosto deve aspirar" (MANUAL DE..., 1853, p. 140).

O "grã-fino" era socialmente inferior ao cavalheiro, e a resposta de Pen a ter Foker como modelo é confusa, pois ele "não é mais refinado que nos tempos de escola" (THACKERAY, 1999, p. 28). No entanto, ele aprecia os relatos de Foker acerca da vida na universidade e resolve ir para Oxbridge, aquela invenção romanesca. Uma vez na universidade, ele percebe que "um ou dois rapazes muito vulgares, que nem mesmo usam tiras em suas calças [...] superam-no completamente na sala de aula". Esse desencontro entre o sucesso na academia e no vestir-se, no entanto, não o preocupa por muito tempo. Quando ele volta para casa, sua prima Laura nota a "quantidade de roupas novas e finas que ele trouxe com ele", e Pen aparece "em lindas jaquetas de tiro [...] maravilhosos coletes de veludo, com gravatas ricamente bordadas". Bisbilhotando no quarto dele, Laura encontra um saco de viagem "com montantes de prata e uma quantidade de adoráveis anéis e joias" (THACKERAY, 1999, p. 172, 212, 213). Vemos, aqui, uma mudança de paradigma do modelo de Brummell/major Pendennis para um novo conceito de sucesso no vestir-se, aquele do Conde D’Orsay, juiz da sociedade londrina na década de 1830.

D'Orsay trouxe suavidade feminina, cor e brilho para a austeridade de Brummell; para Ellen Moers, "[S]eu dandismo era feito de coisas mais frágeis” (MOERS, 1960, p. 148). Pen, com suas gravatas, coletes e joias, também não é feito de material muito rígido. A imagem de Pen agora tem como modelo D’Orsay - seu encanto, seus cachos ruivos e, o mais importante, seu papel como líder da moda, pois é isso que Pen, sem qualquer esforço, acaba por se tornar: "Quando os rapazes ouviam [...] que o Sr. Pendennis havia encomendado uma gravata de cetim vermelho, você veria algumas dúzias de gravatas de cetim vermelho na rua 
principal [...] o joalheiro era conhecido por não vender menos que duas grosas de pingentes Pendennis" (THACKERAY, 1999, p. 219).

As ambições de Pen são inteiramente autoindulgentes e Thackeray não minimiza o custo do modo de vida dele. Mas também ouvimos sobre a exuberância de Pen, seus prazeres e popularidade, aquela "ingenuidade impecável" que caracteriza o herói da vida moderna de Balzac. Ele não é movido pela sedução, pela revolução ou pela vingança. 0 inimigo chega, no entanto, na forma de contas a pagar. Pen é reprovado e volta para casa com apenas dois botões de ouro em seu nome. Ao falhar em obter as qualificações necessárias para ter um trabalho produtivo, Pen rejeitou os valores da classe média vitoriana e optou pelo glamour dos grandes do Antigo Regime.

Entediado em casa, Pen vai para Londres estudar, financiado pelas mulheres de sua família. Ele é declarado um "homem de peso" e se entrega a uma rodada dos prazeres de Londres. No entanto, ele divide sua acomodação com um terceiro, e definitivamente válido, modelo: George Warrington. 0 major se assusta ao ver Warrington "em uma jaqueta de tiro velha e esfarrapada [...] bebendo cerveja” (THACKERAY, 1999, p. 372, 362), mas decide que ele é um cavalheiro. Warrington é o Homem de Jaqueta de Thackeray, uma figura que ele criou em 1841 em um de seus artigos antidândis, Homens e paletós (Men \& jackets), no qual ele transformou "a jaqueta simples, masculina e majestosa" em um símbolo moral: "um homem DE JAQUETA é um homem. Todos os grandes homens usavam jaquetas" (THACKERAY, s/d, p. 611). Em 1850, a jaqueta do trabalhador estava realmente ascendendo na escala social, finalmente tornando parte do agora familiar terno. 0 lado evangélico de Thackeray era atraído pela sua austeridade singela, mas, em sua obra ficcional, seu faro para o absurdo garante que homens de jaqueta e dignos como Warrington não prevaleçam. Uma vinheta de Warrington resgatando o manuscrito do romance de Pen do fogo mostra-o em uma jaqueta peluda, em contraste com o paletó mais fino de Pen. Warrignton diz a Pen que ele é "um maricas [...] mimado por mulheres" (THACKERAY, 1999, p. 393), mas essas observações estimulantes não têm qualquer efeito. Com o sucesso do romance resgatado, Pen, "em suas melhores correntes, abotoaduras e frentes de cambraia” (THACKERAY, 1999, p. 435), torna-se um ídolo literário.

O foco cada vez maior de Thackeray em joias é a preocupação novelística com detalhes externos "para combinar com a noção de frivolidade" que Hollander (1978, p. 424) observa com relação à vestimenta feminina na ficção. Quando Pen, em seu modo despreocupado, fica com a cockney Fanny Bolton, esse foco se intensifica. Desfilando com ele em Vauxhall, ela pensa em como "as calças de lona holandesa branca e seu chapéu branco [...] correntes douradas e abotoaduras, davam-lhe o ar de um príncipe de sangue" (THACKERAY, 1999, p. 626). Ele então a abandona, mas ela se recusa a acreditar que Pen é perverso - "o bom, o grande, o magnificente jovem, com as correntes de ouro e o cabelo ruivo perfumado" (THACKERAY, 1999, p. 650). A última visão que ela tem de Pen é nas corridas de Epsom, de luto pela morte de sua mãe, mas um luto cujo efeito calculado é o apelo sexual: "Lá estava ele [...] dandificado, arrogante, com crepe preto sobre seu chapéu branco e botões negros na frente de sua camisa: e um cravo em seu paletó, que provavelmente alguém tinha lhe dado; com justíssimas luvas cor de lavanda costuradas com preto [...] as bugigangas na corrente 
de seu relógio, o anel em sua mão sob a luva, a bota impecável e brilhante" (THACKERAY, 1999, p. 748). Os detalhes do estilo são quase chocantes e, em termos de perspectiva e descrição no romance realista, atordoantes. "Vale a pena seguir o movimento de foco no texto", diz George Hughes (2002, p. 58) em seu livro Reading novels. Fanny, embora observe Pen à distância, pormenoriza minuciosamente a aparência dele: a proximidade do foco dela, por um lado irreal, tem, por outro, uma amarga intensidade sexual que é psicologica e inteiramente real.

Alguma retribuição deve certamente se seguir a essa exibição triunfante, pois durante o decorrer do romance Pen esgotou o seu dinheiro, o de sua mãe e o de Laura com o único objetivo de se adornar e se divertir. 0 fracasso foi relevado, a penitência foi apenas periódica e os modelos sensíveis que ele teve foram ignorados. Mas Thackeray recompensa Pen com uma renda e um casamento com Laura. A última vez que nós o vemos é na manhã de seu casamento, "usando um novo chapéu, um novo fraque azul [azul novamente] [...] em um novo colete elegante, novas botas e novas abotoaduras" (THACKERAY, 1999, p. 972). Seria essa a imagem da modernidade bem-sucedida? - o adjetivo "novo" é, afinal, repetido cinco vezes. Thackeray ama detalhes, mas foge de análises. Nós nunca "vamos aos bastidores" de Pen, como fazemos com as paixões de Julien e os medos de Lucien, portanto, no dizer de Henry James, "devemos adivinhar o não visto pelo visto [...], traçar as implicações das coisas” (JAMES, 1984a, p. 53).

0 visual de Pen não é nem o do grã-fino nem o do valoroso vitoriano; ele opta, ao contrário, pelo estilo de Regency Buck - distinto e erótico. Por quê? Há, como Ellen Moers aponta, um forte elemento pessoal no tratamento que Thackeray dá a Pen: "Ele queria ser Pen: o que seu eu maduro condena [...] é o mundo dos sonhos do seu eu mais jovem" (MOERS, 1960, p. 207). Mario Praz chama a atitude de Thackeray em relação ao progresso moderno de "elegíaca e melancólica" - as partes mais bem-sucedidas de seus romances "são sempre as descrições da juventude do protagonista" (PRAZ, 1969, p. 240, 243). Thackeray não pode punir Pen por realizar seus próprios sonhos. Quanto mais rica a imagem da juventude de Pen se torna, mais inexoravelmente drenada é a da sua vida adulta. Warrington, em sua jaqueta peluda é, claro, o homem que Thackeray achava que deveria ser; mas, como ele disse sobre si mesmo, "estou andando por aí em 1828 em um paletó azul com botões de latão, um agradável colete marcado, olhando belos seres em mangas de gigot” (THACKERAY, s/d, p. 440). E, embora o paletó do casamento de Pen seja o agora nada atraente fraque, podemos notar que ele é azul, o paletó azul da Arcádia perdida de Thackeray. Pen, como Julien, de Stendhal, fica preso entre aceitar de alguma forma o mundo e permanecer fiel a ideais derrotados. A figura solitária de Pen em um paletó azul permite que o ideal de Thackeray tome uma última posição antes que os muros da domesticidade vitoriana se fechem ao seu redor.

0 que faz esses heróis mais vivos - obsessivamente preocupados com o vestir e o sucesso em um local limite entre o regime antigo e a sociedade burguesa que eventualmente leva à modernidade industrial -, é a inabilidade de ele perceberem seus mundos. Eles constroem hierarquias, imaginam ordens sociais, sacerdócios, elites, hierarquias militares: distintivos necessários para entrar no coração do novo mundo, para ser bem-sucedido com o dinheiro e com as questões do coração. 0 romance constrói e enriquece nossas imagens 
desse processo em toda a sua amplificação e complexidade burguesas: homens tornam-se exibidos em paletós azuis, ou figuras arrojadas na dança do vermelho e do negro, ou objetos sexuais com luvas cor de lavanda e anéis de ouro. 0 vestir os faz e desfaz; escreve-os em seus mundos e sugere que eles pausem para nós. Em nosso mundo, no qual Bill Gates transformou em uniforme de trabalho o jeans e a camiseta de malha, podemos imaginar, por meio dos romances, o que nos trouxe até onde estamos agora. E as confusões em torno da vestimenta nos romances podem nos lembrar, forçosamente, que ainda não sabemos (em relação ao vestir) onde estamos agora. 


\section{Referências}

BALZAC, Honoré de. As ilusões perdidas. São Paulo: Penguin Classics Companhia das Letras, 2011.

BALZAC, Honoré de. Tratado da vida elegante: ensaios sobre a moda e a mesa. Tradução Rosa Freire D’Aguiar. São Paulo: Penguin Classics Companhia das Letras, 2016.

BARTHES, Roland. Sistema da moda. São Paulo: WMF Martins Fontes, 2009.

GOETHE, Johann Wolfgang. Os anos de aprendizado de Wilhelm Meister. Tradução Nicolino Simone Neto. São Paulo: Ensaio, 1994.

GOETHE, Johann Wolfgang. Os sofrimentos do jovem Werther. Tradução Marcelo Backes. Porto Alegre: L\&PM, 2010.

HARVEY, John. Men in black. Chicago: University of Chicago Press, 1995.

HOLLANDER, Anne. Seeing through clothes. Nova York: Avon, 1978.

HOLLANDER, Anne. The fabric of vision. Londres: National Gallery, 2002.

HUGHES, George. Reading novels. Nashville: Vanderbilt University Press, 2002.

JAMES, Henry. Literary criticism. 2 v. Nova York: Library of America, 1984.

MENDEHLSOHN, Daniel. Lost in Versailles. New York Review of Books, v. 53, n. 19, 30 nov. 2006.

MOERS, Ellen. The dandy. Londres: Secker and Warburg, 1960.

MORETTI, Franco. The way of the world. Londres: Verso, 2000.

PRAZ, Mario. The hero in eclipse. Oxford: Oxford University Press, 1969.

RICHARD, Jean-Pierre. Littérature et sensation: Stendhal et Flaubert. Paris: Éditions du Seuil, 1954.

STENDHAL. 0 vermelho e o negro. Tradução Paulo Neves. Porto Alegre: L\&PM, 2013.

THACKERAY William. Men \& jackets [1860]. In: THACKERAY, William. Complete works. V. 13. Oxford: Oxford University Press, s/d.

THACKERAY, William. Pendennis [1850]. Oxford: World Classics, 1999. 